\title{
"Do South African state-owned entities follow the pecking order theory of capital structure?"
}

\begin{tabular}{|c|c|c|}
\hline AUTHORS & \multicolumn{2}{|l|}{$\begin{array}{l}\text { Ferina Marimuthu (i) } \\
\text { Stephanie Caroline Singh (iD) }\end{array}$} \\
\hline ARTICLE INFO & \multicolumn{2}{|c|}{$\begin{array}{l}\text { Ferina Marimuthu and Stephanie Caroline Singh (2021). Do South African state- } \\
\text { owned entities follow the pecking order theory of capital structure?. Public and } \\
\text { Municipal Finance, 10(1), 25-33. doi:10.21511/pmf.10(1).2021.03 }\end{array}$} \\
\hline DOI & \multicolumn{2}{|c|}{ http://dx.doi.org/10.21511/pmf.10(1).2021.03 } \\
\hline RELEASED ON & \multicolumn{2}{|l|}{ Friday, 21 May 2021} \\
\hline RECEIVED ON & \multicolumn{2}{|l|}{ Thursday, 11 March 2021} \\
\hline ACCEPTED ON & \multicolumn{2}{|l|}{ Friday, 14 May 2021} \\
\hline LICENSE & \multicolumn{2}{|c|}{$\begin{array}{l}\text { This work is licensed under a Creative Commons Attribution } 4.0 \text { International } \\
\text { License }\end{array}$} \\
\hline JOURNAL & \multicolumn{2}{|l|}{ "Public and Municipal Finance" } \\
\hline ISSN PRINT & \multicolumn{2}{|l|}{$2222-1867$} \\
\hline ISSN ONLINE & \multicolumn{2}{|l|}{$2222-1875$} \\
\hline PUBLISHER & \multicolumn{2}{|c|}{ LLC “Consulting Publishing Company "Business Perspectives" } \\
\hline FOUNDER & \multicolumn{2}{|c|}{ LLC “Consulting Publishing Company "Business Perspectives" } \\
\hline$\sigma^{0}$ & 15 & 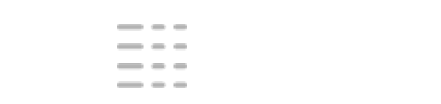 \\
\hline NUMBER OF REFERENCES & NUMBER OF FIGURES & NUMBER OF TABLES \\
\hline 24 & 0 & 5 \\
\hline
\end{tabular}

(c) The author(s) 2021. This publication is an open access article. 


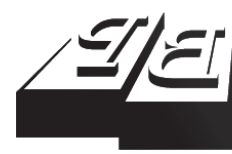

BUSINESS PERSPECTIVES

$\odot$

LLC "CPC "Business Perspectives" Hryhorii Skovoroda lane, 10, Sumy, 40022, Ukraine www.businessperspectives.org
Received on: $11^{\text {th }}$ of March, 2021 Accepted on: $14^{\text {th }}$ of May, 2021 Published on: $21^{\text {st }}$ of May, 2021

(C) Ferina Marimuthu, Stephanie Caroline Singh, 2021

\section{DO SOUTH AFRICAN STATE-OWNED ENTITIES FOLLOW THE PECKING ORDER THEORY OF CAPITAL STRUCTURE?}

\begin{abstract}
In corporate finance, the pecking-order theory suggests that companies adhere to a particular financing hierarchy, with internal funding taking preference over external funding, and debt financing taking preference over equity. This paper examines whether South African state-owned entities prioritize their financing sources as predicted by the pecking-order theory. A financing deficit variable comprising various cash flowbased components was used to test the theory. A panel regression model was employed using panel data estimators. Using a cross-section sample of 33 state-owned entities from 1995 to 2018, the study finds no evidence that South African state-owned entities follow a pecking order to finance investment projects. The pecking order theory proposition that costs of adverse selection are dominant for lower levels of leverage provides a reason for the financing deficit coefficient not being close to unity and hence an indication that the SOEs in South Africa do not follow the pecking order behavior in their financing decisions, an indication that South African capital market is still developing.
\end{abstract}

Keywords

pecking order, capital structure, financing deficit, leverage, fixed effects, random effects, ordinary least squares

Ferina Marimuthu, Ph.D. in Finance, Department of Financial Accounting, Durban University of Technology, South Africa. (Corresponding author)

Stephanie Caroline Singh, M.Acc., Department of Management Accounting, Durban University of Technology, South Africa.

This is an Open Access article distributed under the terms of the Creative Commons Attribution 4.0 International license, which permits unrestricted re-use, distribution, and reproduction in any medium, provided the original work is properly cited.

Conflict of interest statement: Author(s) reported no conflict of interest

\section{JEL Classification G31, G32}

\section{INTRODUCTION}

The pecking-order theory (POT) suggests that companies follow a particular financing hierarchy, where internal financing is preferred over external financing, and debt financing is preferred over equity (Myers, 1984). Hence, the main assumption is that there is a pecking order of corporate financing, where investments are financed first through retained earnings, then debt and finally external equity, as companies would instead use debt financing when internal sources of finance are inadequate to finance expenditure. The theory suggests that the non-existence of the target-debt ratio and the observed-debt ratio reflects the company's collective requirement for external financing. Therefore, the theory suggests that all financing sources are considered by management, and then the cheapest source will be used (De Vries, 2010). Under the POT, companies do not have an optimum debt level for the reason that equity exists at both the top (internal equity) and bottom (external equity) of the pecking order (Myers, 1984, p. 581).

State-owned entities (SOEs) are instrumental in driving the government's developmental objectives. In an emerging economy such as South Africa, these include reducing unemployment, inequality and poverty. To achieve this mandate, the entities are expected to remain financially sustainable over the long term without posing a risk to the 
national resources. Hence, these entities require an optimal mix in their capital structure to finance investments that will generate sufficient funds to allow them to remain financially sustainable over the long term. Some of these public entities have unsustainable business models as the capital structures employed are dependent on debt. Therefore, this may significantly affect the broader public finances, which may deter economic growth (Marimuthu, 2020).

An incorrect choice of capital structure for a firm may result in financial distress, often a harbinger of bankruptcy. Nevertheless, ever since its theoretical rise, controversy has surrounded the debate on the mix of the sources of finance that encompass the optimal debt level. Despite the plethora of empirical investigations, there is no precise formula to determine the optimal capital structure. Hence, this paper aims to determine whether the POT applies to the state-owned entities in South Africa. This paper examines whether these entities follow the financing pattern theorized by the POT based on a crosssection of data from South African state-owned entities. Subsequently, the paper is structured and discussed in the following order: Literature review, the POT and the concomitant empirical evidence are presented in Section 1; the methodology is explained in Section 2; the empirical findings are presented in Section 3; Section 4 provides model specification tests; the last section discusses the conclusions reached.

\section{LITERATURE REVIEW}

\subsection{The theory}

In 1984, the POT was popularized by Stewart Myers and Nicolas Majluf. Given the fact that this is a well-known theory, a brief discussion follows. According to Shyam-Sunder and Myers (1999), the POT predicts that the internal financing deficit drives the external debt financing that drives the external debt financing, whereby an outflow of capital causes a financing deficit by the same amount. The retained earnings, debt, and equity are three financing sources, which are offered to companies. From the investors' viewpoint, equity is riskier than debt; therefore, a greater rate of return may be required with regards to equity. The firm's viewpoint indicates that retained earnings are preferred over debt, while debt is preferred over equity. As a result, projects will be funded firstly using retained earnings, and when this is exhausted, debt will be utilized. Equity is a last resort due to the high financial distress costs of debt or if debt capacity has been exhausted. Under normal operating conditions, the firm does not use equity to finance investments, resulting in the financing deficit matching the net debt issues. A financing deficit variable may be used to test the POT, which is a factor of various cash flow-based components constructed by summing the dividends, working capital, investments, and internal cash flows.
The POT rests on the assumption of asymmetric information. When firms use external debt or equity financing, the return demanded by investors and creditors is higher, since they are less-informed than well-informed managers, possessing more information about the firm. This results in managers obtaining finance in the following order: "retained earnings, debt, convertible debt, preference shares and lastly, new equity issues" (De Wet, 2006). When information asymmetries are high, this tends to increase the risk for outside investors who demand a premium, resulting in the high cost of equity (Elomo, 2014).

The financing deficit was defined as "the use of external debt financing to cover the internal financing deficit's inadequacy on a one-to-one basis" by Shyam-Sunder and Myers (1999). The authors suggested that the financing deficit is equal to the net long-term debt and equity issues. Over the years, researchers have measured the financing deficit using various components, including dividends, investments, working capital, cash flows and longterm debt, amongst others.

The POT empirical tests follow two methods. The first method considers whether particular firm-specific factors behave in a certain way when debt levels change, while the second method observes the impact of the financing deficit on levels of debt. 
Shyam-Sunder and Myers (1999) tested the theory by modelling debt using net debt, gross debt and change in debt against the financing deficit using 157 American companies from 1971-1989 as the sample. The simple pecking order model results showed strong POT support, with regression coefficients of 0.75 and $\mathrm{R} 2$ of 0.68 , which can be interpreted as 75 cents of debt for every dollar of external funds required. Considering that the sample was reduced due to continuous information on the flow of funds, the findings were not generalized via a more representative sample, resulting in serious drawbacks. Given these limitations with the Shyam-Sunder and Myers study, Frank and Goyal (2003) expanded the sample to take account of all companies (768) during the same period after suggesting that the empirical findings did not hold for a larger sample. Their results show a deficit coefficient of 0.75 and R2 of 0.71 supported by ShyamSunder and Myers (1999). However, this was when net debt was used as a dependent variable, and no gaps were permitted in the data. However, they showed weak support for the POT when gaps were permitted in the reporting, with coefficients of 0.28 for the deficit variable and $\mathrm{R} 2$ of 0.27 . In later periods, under the same restrictions, they found weaker support for the POT, where external equity became more popular. The authors illustrate that the pecking order model's performance is affected by the company's size, with smaller companies relying more frequently on equity financing. Fama and French (2002) stated that this is contrary to the POT's predictions, where smaller companies are characterized by higher information asymmetries and should use more debt financing.

Lemmon and Zender (2010) are among other authors who have expanded on the Shyam-Sunder and Myers model. These authors found that by incorporating debt capacity, the concept is a better predictor of the financing behavior of large companies studied over a more extended period. Their results indicated that the model is the best method for companies that are not limited by debt issues. Using the same sample, their results showed a financial deficit coefficient of 0.79 after controlling for the effects of larger deficits by including a quadratic term of the deficit, as compared to 0.75 of the Shyam-Sunder and Myers model. They also modelled debt capacity in terms of whether companies had access to public debt markets. The authors fur- ther argued that credit ratings relate to companies' debt capacity, where a firm has fewer restrictions in issuing debt if their debt outstanding is rated, whereas one that has no rated debt outstanding does not portray pecking order behavior due to the debt issuing constraints imposed by their debt capacity. This is supported by the results of their study, which uses a logit model in which a company's credit ratings are the dependent variable. Firm-specific factors are the independent variable, so they control for excluded companies that have high credit ratings but do not access public debt. They concluded that if debt capacity is controlled, this would show that the POT is a respectable descriptor of the firm's financing behavior.

Chirinko and Singha (2000) pointed out that companies that face debt capacity constraints cannot finance the financing deficit purely with debt, which would result in a financial deficit coefficient of less than one even though the firm may be following a pecking order. They added that companies that have debt capacity constraints would finance only small financing deficits with debt and large deficits with equity financing.

Cross (2010) study of 702 Australian companies from 1995 to 2009 established that when applying the Frank and Goyal (2003) model, with certain restrictions in place, lower coefficients of 0.553 and R2 of 0.402 versus 0.75 and 0.71 , respectively, were revealed. When replicating the Frank and Goyal (2003) model, results indicated a higher coefficient of 0.450 and improved descriptive power with R2 of 0.364 as compared to 0.28 and 0.27 , respectively. However, the findings on firm size also supported the POT to a lesser consistent degree. Coefficients from small to large companies ranged between 0.413 (R2 of 0.348) and 0.510 (R2 of 0.342). Smaller companies are expected to face higher costs related to asymmetries and, therefore, be more reluctant to issue equity and prefer debt. The author concluded that Australian companies finance most of their deficit with debt. However, the static trade-off theory is also not supported as companies are constrained by debt and do not tackle significant capital expenditure, instead reducing leverage towards optimum level.

In summary, these results show that the trade-off model is not supported, and the pecking-order 
model has a lower explanatory power. The reasoning behind this is that Australia relaxed the tax advantage of debt, and there is greater use of warrants and rights that has lower asymmetric information costs. Cross (2010) used a quadratic term, which allows for a non-linear relationship between the financing deficit and the debt issuance in the model, and used dummy variables to discern between financial surplus and financial deficit. Ağca et al.'s (2010) study produced similar findings, although it used a piecewise linear specification.

Verwijmeren (2008) suggested that the financial deficit becomes positive when squared when using a quadratic term of the financing deficit. When the correlation between the financing deficit, debt capacity, and companies' financing decisions were tested, the effect of surpluses was considered. The results indicated that when companies had rated debt outstanding with small financing deficits, they discovered a higher coefficient $(0.802)$ than those with non-rated debt outstanding (0.649). On the other hand, companies with rated debt outstanding with large financing deficits had a lower coefficient of 0.297 , and an even lower coefficient of 0.093 was found for companies without rated debt outstanding. The findings confirmed those of Lemmon and Zender (2010), who concluded that rated companies have higher pecking-order coefficients concerning financing deficits, than non-rated companies. Research has shown that subject to constrained debt capacity, companies prefer to issue debt when external funding is required, hence the widespread support for the POT (Cross, 2010).

\section{METHOD}

\subsection{Data}

The state-owned entities' annual reports and financial statements were obtained using McGregor BFA Library and Bloomberg online databases. Data was obtained for the period 1995 to 2018 from thirty-three commercial state-owned entities, which were listed under the Public Finance Management Act in Schedule 2 (Major Public Entities), Schedule 3B (National Business Enterprises) and Schedule 3D (Provincial Business Enterprises).

\subsection{Variables and measures}

This section discusses the variables used to test the predictions of the POT. Previous empirical studies guided the selection of variables for inclusion in the model together with the POT predictions. These variables are shown in Table 1.

Leverage was measured as the change in net debt issued so that short-term and long-term debts are incorporated in the financing deficit. Short-term debt, such as trade credit, also provides financing when companies would otherwise be constrained (Verwijmeren, 2008).

The financing deficit (DEF) was defined as using the cash flow to increase the assets supposed to be less than the change in current liabilities and retained earnings (Yulianto et al., 2016). The implication is that the retained earnings should guarantee the current liabilities, which should be greater than asset purchases. Regarding the financing deficit, where the retained earnings are less than the current liabilities, which are less than the asset purchases, its needs are met through external debt financing in terms of the pecking-order model. When the firm needs to make dividend and investment payments and increase working capital, which is more than the cash flows generated, the condition for the financing deficit occurs.

Table 1. Variables and measures: Pecking order model

Source: Frank and Goyal (2003), Fama and French (2002), Chirinko and Singha (2000), Shyam-Sunder and Myers (1999).

\begin{tabular}{|c|c|c|}
\hline Variable & Measurement & Formulae/proxy \\
\hline $\begin{array}{l}\text { Independent } \\
\text { variable: } \\
\text { Financing } \\
\text { deficit }\end{array}$ & Def & $\begin{array}{c}\text { Dividend payments + capital } \\
\text { expenditures + change in } \\
\text { working capital - operating } \\
\text { cash flows after interest } \\
\text { and tax }\end{array}$ \\
\hline $\begin{array}{l}\text { Dependent } \\
\text { variable: Net } \\
\text { debt issued }\end{array}$ & $\Delta \mathrm{TD}$ & $\begin{array}{l}\text { Current total debt - } \\
\text { previous year's total debt }\end{array}$ \\
\hline
\end{tabular}

\subsection{Model specification}

The model developed in this section will test whether South African SOEs follow a financing hierarchy in their capital structure as theorized by the POT. The model is based on a simple panel regression model adapted from prior studies where the model was tested in the private sector of developed 
and developing economies (Frank \& Goyal, 2003; Fama \& French, 2002; Chirinko \& Singha, 2000; Shyam-Sunder \& Myers, 1999).

The specified equation (1) is based on the original financial deficit model by Shyam-Sunder and Myers (1999), who tested the POT's expectations by regressing the change in debt against the categories of financing used to cover the financing deficit. The interpretation of this simple pecking order model is that the closer $\beta_{p o t}$ is to 1 , the stronger the support for the POT, and when $\beta_{p o t}$ is equal to one, this implies that all external funding requirements will be funded purely by debt.

$$
\Delta D_{i t}=\propto_{i t}+\beta_{p o t} D E F_{i t}+\mathrm{E}_{i t},
$$

where $\Delta D_{i t}$ - amount of long-term debt issued; $\beta_{p o t}$ - pecking order coefficient; and $D E F_{i t}$ - financing deficit.

The financing deficit (DEF) can be measured as follows:

$$
D E F_{t}=D I V_{t}+X_{t}+\Delta W_{t}+R_{t}-C_{t},
$$

where $D I V_{t}$ - dividend payments; $X_{t}$ - capital expenditures; $\Delta W_{t}$ - net increase in working capital - change in operating working capital + change in cash and cash equivalents + change in current debt; $R_{t}$ - current portion of long - term debt; and $C_{t}$ - operating cash flows after interest and tax.

A positive financing deficit indicates a firm investing more in cash than internally generated funds. In contrast, a negative financial deficit indicates investing less in investments than internally generated funds and increased internal operating cash flows (Kayhan \& Titman, 2007). When companies raise capital, there is a stronger effect of a positive financial deficit on the capital structure, than when companies pay out capital, and the financing deficit is negative (Lew, 2013).

Equation (1) is the least complex approach of testing the POT without any restrictions with the advantage that observations are not lost, which is usually the case when control variables are included, and hence, Frank and Goyal (2003) modified equation (2) by removing the portion of long-term debt, which was current, as this was contained within the change in working capital.

Chirinko and Singha (2000), De Jong et al. (2010), and Lemmon and Zender (2010) made further modifications to the original Shyam-Sunder and Myers (1999) model to include the size of the financing deficit and whether the deficit was negative (surplus) or positive (deficit). Cross (2010) further modified the models by the above authors to include short-term debt on the left of the equation and exclude the short-term debt from the change in working capital. The author explained that both long-term and short-term debts are regarded as a source of external funding and that the POT is not based on the time structure of debt used to fund financing deficits. Furthermore, the timing of the debt can have severe implications for working capital considering that when the long-term debt expires within twelve months, it is then reclassified as a short-term debt in the statement of financial position, resulting in a large financing deficit due to its effect on working capital (Cross, 2010).

Revised model specification:

$$
\begin{aligned}
& D E F_{t}=D I V_{t}+X_{t}+\Delta W_{t}-C_{t}, \\
& \Delta T D_{i t}=\propto_{i t}+\beta_{p o} D E F_{i t}+\mathrm{E}_{i t} .
\end{aligned}
$$

where $\Delta W_{t}=$ inventory + debtors + cash and cash equivalents - creditors; $\Delta T D_{i t}=$ change in the long-term debt and change in the short-term debt.

Frank and Goyal (2003) used net assets, total book assets, and sales to scale the variables and found similar results in all three scaling methods. The authors explained that it is conventional to scale variables as a means for controlling for differences in the firm's size and scaling can be done using total assets or sales, provided that the same value scales both the right and the left side, then the equivalence remains unhindered.

A $\breve{c c a}$ et al. (2010) and De Jong et al. (2011) used total assets to scale the variables, whereas Cross (2010) and Lemmon and Zender (2010) scaled the financing deficit and the total debt variance using the book value of total assets from the year prior. Regarding the regression equation specified, if the scaling variable is correlated with the regressed 
variables, this will affect the estimated coefficient. This study will follow that of Vicol (2010), where the variables were unscaled as the author did not want to risk manipulating the coefficients.

\subsection{Estimation methods}

The use of panel data offers advantages in econometric analysis; however, the observations can no longer be independent. Estimators such as Random Effects (RE), Fixed Effects (FE) and Ordinary Least Squares (OLS) are often used to account for these unobservable effects in a linear panel data model, such as the pecking order model specification in this study.

The assumptions required to achieve efficient estimates are different for these estimators; hence, it is necessary to conduct tests. These included the Hausman test and the Breusch-Pagan test. The key differences between the estimators are presented in Table 2.

Table 2. Differences between FE, RE and OLS estimators

Source: Wooldridge (2010), authors' own construction.

\begin{tabular}{|c|c|c|}
\hline FE & RE & OLS \\
\hline $\begin{array}{l}y_{i t}=x_{i t} \cdot \beta 1+\varepsilon_{i t^{\prime}} \text { where } \\
\text { specification for } \\
\text { the error terms: } \varepsilon_{i t} \\
=\alpha_{i}+u_{i t^{\prime}} \text { where } \alpha_{i} \\
\text { unit-specific, time- } \\
\text { constant factors }\end{array}$ & $\begin{array}{c}y_{i t}=60+x_{i t} \cdot \beta 1 \\
+\varepsilon_{i t} \text { where } \\
\text { specification for } \\
\text { the error terms: } \varepsilon_{i t} \\
=\alpha_{i}+u_{i t}\end{array}$ & $\begin{array}{c}y_{i t}=\beta 0+x_{i t} \cdot \beta 1+\varepsilon_{i t,} \\
\text { where specification } \\
\text { for the error terms: } \\
\qquad \varepsilon_{i t}=\alpha_{i}+u_{i t}\end{array}$ \\
\hline $\begin{array}{c}\alpha_{i} \text { may be correlated } \\
\text { with } x_{i t}\end{array}$ & $\begin{array}{l}\alpha_{i} \text { and } u_{i t} \text { are } \\
\text { assumed to } \\
\text { be mutually } \\
\text { independent and } \\
\text { correlated with } x_{i t}\end{array}$ & $\begin{array}{c}\alpha_{i} \text { may be } \\
\text { correlated with } x_{i t}\end{array}$ \\
\hline Strict exogeneity & Strict exogeneity & Strict exogeneity \\
\hline $\begin{array}{l}\varepsilon_{i t} \text { is serially } \\
\text { uncorrelated }\end{array}$ & $\begin{array}{l}\varepsilon_{i t} \text { is serially } \\
\text { uncorrelated }\end{array}$ & $\begin{array}{c}\varepsilon_{i t} \text { follows a random } \\
\text { walk (positive } \\
\text { serial correlation } \\
\text { and } \Delta u_{i t} \text { is serially } \\
\text { uncorrelated) }\end{array}$ \\
\hline$\varepsilon_{i t}$ is homoskedastic & $\begin{array}{c}\varepsilon_{i t} \text { is } \\
\text { homoscedastic }\end{array}$ & $\varepsilon_{i t}$ is homoscedastic \\
\hline \multicolumn{3}{|c|}{ Model selection } \\
\hline \multicolumn{3}{|c|}{$\begin{array}{l}\text { HAUSMAN TEST (choose between FE and RE) } \\
\text { bRE: consistent if } x_{i t} \text { and } \alpha_{i} \text { are uncorrelated } \\
\text { bFE: consistent if } x_{i t} \text { and } \alpha_{i} \text { are correlated } \\
H_{0}: \text { RE estimates are consistent } \\
\text { Accept } H_{0}: \text { FE }=R E \Rightarrow \text { Select the RE model } \\
\text { Reject } H_{0}: \text { FE } \neq \text { RE } \Rightarrow \text { Select the FE model }\end{array}$} \\
\hline \multicolumn{3}{|c|}{$\begin{array}{l}\text { BREUSCH-PAGAN TEST (choose between FE and RE } \\
\text { Test for non-constant variance of the error terms } \\
\text { Rejection indicates preference for FE or RE model } \\
\text { Non-rejection indicates preference for OLS model }\end{array}$} \\
\hline
\end{tabular}

To determine the estimator that is more efficient between the RE and FE estimators, the Hausman test is used. When testing for RE, the BreuschPagan Lagrange multiplier (LM) test assists in the decision between RE and OLS estimator. The null hypothesis specified in the LM test shows that the variance is zero across entities. Subsequently, there is no significant variance across units or there is no panel effect.

\section{RESULTS AND DISCUSSION}

An alternate approach to test whether companies' financing behavior follows the POT is that of Shyam-Sunder and Myers (1999), where a variation in debt is considered to determine whether a financial deficit drives the change, and if so, this would confirm the POT. The authors hypothesized a relationship on a oneto-one basis between the change in debt and financing deficit. The data was analyzed and run through STATA to examine the significant correlation between the change in debt and the financing deficit. These results are presented in this section.

Table 3 presents FE, RE and OLS estimates of the financing deficit coefficients used to measure the behavior as hypothesized by the POT. The findings show that the financing deficit, representative of the inadequacy of internal financing for investments and dividend payments, is negatively related to the net debt issued. The financial deficit coefficients had low values in the range of -0.294 to -0.316 and were statistically significant amongst all three models. These coefficients can be interpreted as follows: for every one rand required to cover the financing deficit, 29.4 cents to 31.6 cents is financed with debt. Although the coefficients are far from zero, they are even further from one, which shows that SOEs in South Africa do not support the pecking-order model. The results indicate that the financing deficit will minimize changes in net debt, since SOEs would cover the deficit with other sources of finance, including capital.

There was also low explanatory power as indicated by the R-Squared values, an indication 
Table 3. Regression results: Pecking order model

\begin{tabular}{|c|c|c|c|}
\hline Variable & OLS & $\mathrm{FE}$ & RE \\
\hline \multirow{2}{*}{ Financing deficit } & $-0.294 * * *$ & $-0.316^{* * *}$ & $-0.303^{* * *}$ \\
\hline & $(-17.3)$ & $(-9.79)$ & $(-8.33)$ \\
\hline \multirow{2}{*}{ Constant } & $289,228^{* * *}$ & $241,965^{* * *}$ & $269,596^{* *}$ \\
\hline & $(2.63)$ & $(3.6)$ & $(2.04)$ \\
\hline Adjusted R-squared & 0.3444 & - & - \\
\hline R-squared overall & - & 0.345 & 0.3455 \\
\hline Observations & 558 & 558 & 558 \\
\hline Groups & - & 33 & 33 \\
\hline F-statistic & 293.57 & 95.92 & - \\
\hline Prob. $>F$ & 0.0000 & 0.0000 & - \\
\hline Wald chi2(1) & - & - & 69.41 \\
\hline Prob. > chi2 & - & - & 0.0000 \\
\hline
\end{tabular}

Note: t-statistics ( $\mathrm{OLS}$ and $\mathrm{FE}$ ) and z-statistics (RE) based on robust standard errors clustered at the firm level are reported in parentheses; $* * * p<0.01, * * p<0.05, * p<0.1$.

that approximately $35 \%$ of the difference in the net debt issued is explained by the financing deficit. The F-test results in Table 4, testing whether DEF is equal to unity, are rejected for the OLS and FE models. This indicates that debt issues do a poor job in tracking the financing deficit. The coefficients based on the three estimation methods are all consistent, statistically significant ( $1 \%$ confidence level) and show a negative effect of the financing deficit variable on the change in net debt. These indicate that financial deficits are more related to equity issues to reduce debt and build cash holdings. These findings are similar to those of Fama and French (2004), Lew (2013) and Wiagustini et al. (2017), who also found negative coefficients of the financing deficit and no support for the simple pecking order model. Wiagustini et al. (2017) suggested that companies that seek to use internal sources as funds minimize their risk, which results in lower information asymmetries. If the capital structure follows the POT in the absence of the control variables, the financing deficit coefficient will be unity, as companies only issue safer securities when they need additional capital. Other studies that have found low financing deficit coefficients include Frank and Goyal (2003) and Verwijmeren (2008). These studies also indicated that there was stronger support for the POT in earlier decades that has weakened in recent years.

A high average debt ratio of $56 \%$ was found amongst these SOEs for the reporting period, which indicates that the costs of financial dis- tress are high among South African SOEs, which possibly explains why further debt issues may be curtailed. Other sources of financing are utilized, such as equity or other forms of assistance by the government. For example, a possible solution to Eskom's short-term capital requirements lies in the government taking on a large chunk of Eskom's debt or it could give Eskom cash to settle its debt (Zyl, 2019). In terms of the POT's suggestion that the costs of adverse selection are dominant for "low to moderate" leverage levels, Lemmon et al. (2008) offer reasons why the financing deficit coefficient is not close to unity; hence, the pecking-order model is not supported with regards to these SOEs.

The Hausman test was applied to determine the more suitable estimator in this study between $\mathrm{FE}$ and RE. The Chi-squared presented in Table 4 indicates that the p-value is greater than $5 \%$; therefore, the null hypothesis cannot be rejected. The test results show that the FE and RE difference is not significant; hence, the null hypothesis is accepted: $H_{0}: \mathrm{FE}=\mathrm{RE}$. The RE model is thus selected.

Table 4. Hausman test results

Source: Own construction.

\begin{tabular}{|c|c|c|c|c|}
\hline Variable & $\begin{array}{l}\text { Fixed } \\
\text { effects }\end{array}$ & $\begin{array}{c}\text { Random } \\
\text { effects }\end{array}$ & Difference & S.E. \\
\hline DEF & -0.3163884 & -0.3033671 & -0.0130213 & 0.017737 \\
\hline Chi2(1) & \multicolumn{4}{|c|}{0.54} \\
\hline $\begin{array}{l}\text { Prob. > } \\
\text { chi2 }\end{array}$ & \multicolumn{4}{|c|}{0.4629} \\
\hline
\end{tabular}


The Breusch and Pagan Lagrangian multiplier test for RE presented in Table 5 is significant; hence, the null hypothesis that variances across entities is zero is rejected. It is thus concluded that there are panel effects, and the random effect regression is the appropriate model.
Table 5. Breusch and Pagan Lagrangian multiplier test for random effects

Source: Own construction

$\operatorname{Var}(\mathrm{u})=0$

Chibar2 $(01)=30.23$

Prob $>$ chibar2 $=0.000$

\section{CONCLUSION}

The POT predictions were tested on a cross-section of thirty-three commercial state-owned entities in South Africa from 1995 to 2018. Contrary to suppositions, internal financing is insufficient to cover investment; external financing is severely utilized, and debt financing does not substantially dominate equity financing.

The financing deficit is usually matched one-to-one by a change in debt. Hence, if companies follow the pecking-order, a slope coefficient of one is observed in a regression of net debt issues on the financing deficit (Shyam-Sunder \& Myers, 1999; Frank \& Goyal, 2003). The results presented by FE, RE and OLS estimators reveal that the financing deficit that represents the insufficiency of internal financing for investments and dividend payments, is adversely associated with the net debt issued. The financial deficit coefficients had low values and were statistically significant amongst all three models, which shows that SOEs in South Africa do not support the pecking-order model. The results indicate that the financing deficit will minimize changes in net debt as SOEs would cover the deficit with other sources of finance, including capital. The POT's suggestion that the costs of adverse selection are dominant for lower levels of leverage provides a reason for the financing deficit coefficient not being close to unity. This indicates that South African SOEs do not follow a pecking-order behavior in financing decisions.

\section{AUTHOR CONTRIBUTIONS}

Conceptualization: Ferina Marimuthu.

Data curation: Ferina Marimuthu.

Formal analysis: Ferina Marimuthu.

Investigation: Ferina Marimuthu.

Methodology: Ferina Marimuthu.

Project administration: Ferina Marimuthu, Stephanie Caroline Singh.

Visualization: Ferina Marimuthu, Stephanie Caroline Singh.

Writing - original draft: Ferina Marimuthu.

Writing - review \& editing: Ferina Marimuthu, Stephanie Caroline Singh.

\section{REFERENCES}

1. Ağca, S.., Mozumdar, A., \& Frank, E. F. M. (2010). Corporate Financing Choices Constrained by the Amount of Debt Companies Can Support. Retrieved from http://citeseerx.ist.psu.edu/view$\mathrm{doc} /$ download?doi=10.1.1.556.816 $5 \&$ rep $=$ rep $1 \&$ type $=$ pdf

2. Chirinko, R. S., \& Singha, A. R. (2000). Testing static trade-off against pecking order models of capital structure: a critical comment. Journal of Financial Economics, 58(3), 417-425. https://doi.org/10.1016/S0304405X(00)00078-7

3. Cross, R. (2010). Capital structure and financing choices: an Australian study (Master's Thesis). Massey University. Retrieved from https://mro.massey.ac.nz/ bitstream/handle/10179/3474/02_ whole.pdf
4. De Jong, A., Verbeek, M., \& Verwijmeren, P. (2010). The impact of financing surpluses and large financing deficits on tests of the pecking order theory. Financial Management, 39(2), 733-756. https://doi.org/10.1111/ j.1755-053X.2010.01090.x

5. De Jong, A., Verbeek, M., \& Verwijmeren, P. (2011). Companies' debt-equity decisions when the static trade-off theory 
and the pecking order theory disagree. Journal of Banking \& Finance, 35(5), 1303-1314 https://doi.org/10.1016/j.jbankfin. 2010.10.006

6. De Vries, A. (2010). The effect of firm characteristics and economic factors on capital structures: of South African listed industrial firms (Master's Thesis). Retrieved from https://scholar.sun.ac.za/ handle/10019.1/5163

7. De Wet, J. V. (2006). Determining the optimal capital structure: a practical contemporary approach. Meditari Accountancy Research, 14(2), 1-16. https://doi. org/10.1108/10222529200600009

8. Elomo, P. N. (2014). Determinants of capital structure of start-up firms in South Africa (Master's Thesis). University of the Witwatersrand. Retrieved from http://wiredspace.wits.ac.za/bitstream/ handle/10539/16949/Research\%20 paper_Paginate\%20FINAL.pdf

9. Fama, E. F., \& French, K. R. (2002). Testing trade-off and pecking order predictions about dividends and debt. The Review of Financial Studies, 15(1), 1-33. https://doi.org/10.1093/rfs/15.1.1

10. Fama, E. F., \& French, K. R. (2004). Financing decisions: who issues stock? Journal of Financial Economics, 76, 549-582. https:// doi.org/10.2139/SSRN.429640

11. Frank, M. Z., \& Goyal, V. K. (2003). Testing the pecking order theory of capital structure. Journal of Financial Economics, 67, 217 248. Retrieved from https://www. academia.edu/33850450/Testing_the_pecking_order_theory_ of_capital_structure

12. Kayhan, A., \& Titman, S. (2007) Firms' histories and their capital structures. Journal of Financial Economics, 83(1), 1-32. https://doi. org/10.1016/j.jfineco.2005.10.007

13. Lemmon, M. L., \& Zender, J. F. (2010). Debt Capacity and Tests of Capital Structure Theories. Journal of Financial and Quantitative Analysis, 45(5), 11611187. https://doi.org/10.1017/ S0022109010000499

14. Lemmon, M. L., Roberts, M. R., \& Zender, J. F. (2008). Back to the beginning: persistence and the cross-section of corporate capital structure. The Journal of Finance, 63(4), 1575-1608. https://doi.org/10.1111/j.15406261.2008.01369.x

15. Lew, S. H. (2013). An investigation of the most appropriate capital structure theory and leverage level determinants (Ph.D. Thesis). https://doi.org/10.2139/ SSRN.2339968

16. Marimuthu, F. (2020). Government assistance to stateowned enterprises: a hindrance to financial performance. Investment Management and Financial Innovations, 17(2), 4050. http://dx.doi.org/10.21511/ imfi.17(2).2020.04

17. Myers, S. C. (1984). The capital structure puzzle. The Journal of Finance, 39(3), 574-592. https:// doi.org/10.2307/2327916

18. Shyam-Sunder, L., \& Myers, S. C. (1999). Testing static trade-off against pecking order models of capital structure. Journal of Financial Economics, 51, 219-244. Retrieved from http://people. stern.nyu.edu/eofek/PhD/papers/ SM_Testing_JFE.pdf

19. Verwijmeren, P. (2008). Empirical Essays on Debt, Equity, and Convertible Securities (Doctoral Thesis). Erasmus Research Institute of Management. Retrieved from http://hdl.handle. net/1765/14312

20. Vicol, M. (2010). Capital structure: testing pecking order theory and static trade-off theory in the current crisis (Master's Thesis). Retrieved from http://hdl.handle. net/20.500.11956/26889

21. Wiagustini, N. L. P., Ramantha, I. W., Sedana, I. B. P., \& Rahyuda, H. (2017). Indonesia’s Capital Structure: Pecking Order Theory or Trade-Off Theory. International Journal of Applied Business and Economic Research, 15(16), 119132. Retrieved from https://simdos.unud.ac.id/uploads/file_penelitian_1_dir/1e6dd19f41c735c23fff 61a89269f1a5.pdf

22. Wooldridge, J. M. (2010). Econometric analysis of cross section and panel data. MIT press. Retrieved from https://jrvargas. files.wordpress.com/2011/01/ wooldridge_j-_2002_econometric_analysis_of_cross_section and_panel_data.pdf

23. Yulianto, A., Suseno, D. A., \& Widiyanto, W. (2016). Testing Pecking Order Theory and Trade off Theory Models in Public Companies in Indonesia. International Journal of Economic Perspectives, 10(4), 21-28. Retrieved from http://lib.unnes. ac.id/43898/

24. Zyl, G. V. (2019). Eskom CEO wants government take on some of its massive debt. BizNews. Retrieved from https://www. biznews.com/sa-investing/2019/02/08/eskom-ceo-wantsgovt-take-on-some-of-its-massivedebt 